\title{
Determinants of Family Takaful (Islamic Life Insurance) Demand: A Conceptual Framework for a Malaysian Study
}

\author{
Ahmad Shukri Yazid (Corresponding Author) \\ Faculty of Business Management \& Accountancy \\ Universiti Sultan Zainal Abidin \\ Gong Badak Campus, 21300 Kuala Terengganu, Malaysia \\ Tel: 60-9-665-3751 E-mail: shukri@unisza.edu.my \\ Juliana Arifin \\ Faculty of Business Management \& Accountancy \\ Universiti Sultan Zainal Abidin \\ Gong Badak Campus, 21300 Kuala Terengganu, Malaysia \\ Tel: 60-9-665-3751 E-mail: julianaarifin@unisza.edu.my \\ Mohd Rasid Hussin \\ Professor in Risk Management, College of Business (COB) \\ Universiti Utara Malaysia (UUM), Sintok, Kedah Darul Aman, Malaysia \\ E-mail: mdrasid@uum.edu.my \\ Wan Norhayate Wan Daud \\ Faculty of Business Management \& Accountancy \\ Universiti Sultan Zainal Abidin \\ Gong Badak Campus, 21300 Kuala Terengganu, Malaysia \\ Tel: 60-9-665-3751 E-mail: wnhayate@unisza.edu.my
}

Received: December 6, 2011

Accepted: January 4, 2012 Published: March 16, 2012

doi:10.5539/ijbm.v7n6p115

URL: http://dx.doi.org/10.5539/ijbm.v7n6p115

\begin{abstract}
Family Takaful is one of the service sectors that are expected to continue to drive growth in the economy. Thus, the family Takaful market continues to play an important role in supporting economic and social development. However, in Malaysia, family Takaful market is still at a lower penetration level if we were to compare to other developed countries even though the Takaful industry continues to sustain strong performance amidst challenges in a competitive environment. Evidence has shown that the percentage of society covered by family Takaful contracts in Malaysia is still very low compared to conventional insurance. Therefore, the study aims to propose a conceptual framework for the determinants of family Takaful demand in Malaysia. From a review of the literature available in this particular area of interest, there are two categories of factors that are found to be the main determinants of family Takaful. These factors are the socio-demography and economic factors.
\end{abstract}

Keywords: Family Takaful, Islamic life insurance, Malaysia

\section{Introduction}

Takaful originates from the Arabic word kafalah, which means guaranteeing each other. Takaful is generally known as Islamic insurance because the system is based on the concept of social solidarity, cooperation and mutual indemnification of losses of members. In addition, the Takaful system is perceived as cooperative or mutual insurance, where members contribute a certain sum of money to a common pool. The Takaful system is 
based on the principles of mutual co-operation and responsibility between participants in a group.

The principle of Ta'wun (mutual co-operation) and Tabarru' (donation) means the risk is shared collectively by participants in the group with the overall objective of eliminating the element of uncertainty. For example, a group of persons who agree to jointly indemnify the loss or damage that may be inflicted upon any of them, out of the fund they donate collectively. Helping each other in the event of misfortune is highly encouraged in Islamic teaching. In the Qur'an, Allah mentioned that: “.... Help you one another in Al Birr and At Taqwa (virtue, righteousness and piety); but do not help one another in sin and transgression...." (Al-Maidah: 2).

According to the Ernst and Young World Takaful Report (2011) as cited in the International Insurance and Healthcare Industry news, the global Takaful contribution would increase by 31 percent to USD12 billion in 2011 from USD9.15 billion in 2010. In addition, the rapidly growing Takaful industry is concentrated mainly in Saudi Arabia (making up USD3.86 billion of the industry in 2009), Malaysia (USD1.15 billion), UAE (USD640 million), South East Asia and North Africa.

Besides, by referring to the performance of the Takaful market in the world, most Gulf countries corporations (GCCs) have experienced a slowdown in Takaful growth with only the Saudi Takaful market remaining strong due to the continued rollout of compulsory medical insurance. It also reported that Sudan is the most significant market outside these regions with contributions of USD340 million whereas Egypt, Bangladesh and Pakistan are growing at a rapid pace. Meanwhile, in terms of regions, Takaful contributions on the Indian subcontinent grew by 85 percent; making it the world's fastest growing Takaful market. This was followed by the Levant (40 percent), GCCs (31 percent), Southeast Asia (29 percent) and Africa (26 percent). In terms of individual countries, Indonesia topped the Takaful market with a growth rate of 67 percent, followed by Bangladesh (58 percent) and Saudi Arabia (34 percent).

Generally, the Takaful industry is facing a lower return on equity $(\mathrm{RoE})$ due to the intensified competition that small local firms face from established conventional players. It was disclosed that in GCC, average RoE for conventional insurers was 11 percent while the Takaful sector posted 10 percent in 2010. However, in Malaysia, the average RoE for conventional insurers was 16 percent and only 6 percent for Takaful operators. It was reported that Malaysia claim ratios are significantly lower than the GCC, largely due to the difference in dominant business lines. For example, GCC is dominated by general Takaful whereas in Malaysia it is mostly family Takaful. The family Takaful market remains underpenetrated and is estimated to contribute only 5 percent of gross contribution in the Mena region. While in Malaysia, the Family Takaful was reported as highly penetrated and is estimated to contribute 77 percent of net Takaful contributions in 2010.

\section{Problem Statement}

In the case of Malaysia, the government's aspiration toward Takaful industry is to create an efficient, progressive and comprehensive Islamic financial system that contributes significantly to the effectiveness and efficiency of the Malaysian financial sector while meeting the economic needs of the nation. In line with this, Bank Negara Malaysia deputy director Azleena Idris (2011) stated that the success of the industry lies in its ability to collectively position itself strategically to meet the needs of the economy and the ability to be competitive and innovative.

The Takaful industry is viewed as an attractive business in Malaysia and there are tremendous growth opportunities for the insurance and Takaful industries in supporting the requirements of the economy. According to the Insurance Services Malaysia Berhad (ISM), as cited in Etiqa Takaful Berhad (2011) the Takaful industry in Malaysia has been experiencing steady growth and rapid changes over the last 5 years. This can be seen through its business performance from 2005 to 2009 whereby the total Takaful industry grew by $32 \%$ in 2008 and $14 \%$ in 2009. It is reported that family Takaful new business grew by $36 \%$ in 2008 , but posted a slower growth of $10 \%$ in 2009. At the same time general Takaful grew by $24 \%$ in 2008 and 2009 .

\section{Insert Table 1- here}

The Takaful industry has been blessed with tremendous growth and strong performance. According to EtiqaTakaful Bhd's Chief Executive Officer, Shahril Azuar Jimin in the Evaluation of the Malaysian Takaful Industry (2011), the Takaful market has become more diverse internationally and locally as there has been a tremendous increase in the number of Takaful operators operating worldwide as well as in Malaysia. It showed that there were 181Takaful operators in business worldwide in 2010. Meanwhile, in Malaysia, from just a single Takaful operator in 1984, it had 12 Takaful operators as at 2010. This tremendous increase of Takaful operators in Malaysia provides the opportunities that would lead to expansion of the Takaful market share and increased penetration. 
Although Malaysia's Takaful industry has seen tremendous growth from year to year, it still lags behind its conventional peers in terms of total insurance market penetration and share. According to Takaful Ikhlas Sdn Bhd president and Chief Executive Officer Datuk Syed Moheeb Syed Kamarulzaman (2010), the penetration rate for Takaful in Malaysia was around 10\%, compared with conventional insurance at $40 \%$. In line with this, Syed Moheeb also highlighted that the primary Takaful market was the Muslim segment and the penetration was low due to affordability, lack of appreciation for wealth planning, lack of sharia (Islamic Law) compliant insurance products and awareness of such products. By referring to the total assets of Malaysian insurance and Takaful industry, it showed that the total fund assets for the Takaful industry was only RM6.89 billion in 2006 compared to conventional insurance, RM108.5 billion for the same period. By 2009 the total assets for the Takaful industry had increased by only RM12.4 billion compared to RM148.6 billion for conventional insurance. In terms of the total assets of the insurance and Takaful industry, the percentage for Takaful fund was far behind the conventional insurance (Table 2).

\section{Insert Table 2- here}

It was reported by Ernst \& Young World Takaful Report (2010) that Malaysia remains the largest Takaful market in South East Asia, but still there is a large untapped market that exists with only 54 percent of the population having a life insurance or family Takaful policies (Bank Negara Malaysia, 2010). Due to this untapped market, the Takaful industry in Malaysia is poised to benefit in the years ahead by steady demand. It also represented a strong growth potential that provides opportunity to penetrate the remaining underserved areas in family Takaful. As the Malaysian society transitions to a more ageing population, there is room to harness the appeal of family Takaful as a tool for long term savings and investment, whilst protecting against financial vulnerabilities arising from critical illness, death, disability or unemployment or providing for children's education.

Malaysia intends to improve and achieve greater penetration in the family Takaful market. For that reason, the Malaysian government has introduced several incentives such as personal tax relief for Employees Provident Fund (EPF) and life insurance or Takaful premiums from RM5,000 to RM6,000. In addition, new parliamentary initiatives from government such as the New Economic Model (NEM), Economic Transformation Program (ETP) and the Tenth Malaysian Plan would lead to the growth in demand for Takaful products and services. On the other hand, the sales promotion and marketing activities by Takaful operators would be used to promote Takaful products and services among Malaysians as a form of protection and financial planning.

All these initiatives could be among the main engines to achieve the targets in improving the low level of Takaful penetration rate in the country. Despite many incentives provided by the Malaysian government as a way to encourage more Malaysians to purchase family Takaful as well as to support the development of this industry in Malaysia, it is worthwhile to highlight that the majority of the population is still underinsured. Following this, an important question needs to be answered: what are the determinants for family Takaful demand?

From the literature review, there is very little research in the field of family Takaful. Therefore, this particular study would provide new insight into the factors that influence people to buy family Takaful products. Thus, this study could fill a gap in the family Takaful literature.

\subsection{Research Objectives}

The main objectives of this study are:

1) To identify the determinants of family Takaful demand;

2) To develop a new model for determinants of family Takaful demand.

\subsection{Research Questions}

In order to achieve the objectives, the study will answer the following research questions:

1) What are the determinants of family Takaful demand?

2) What is the new determining model of family Takaful demand?

\section{Literature review}

\subsection{Family Takaful}

Family Takaful plans are generally used for family solidarity in place of conventional life insurance which provides protection, long-term savings and an investment instrument. It provides a mutual guarantee of financial assistance in the event of death to the participant. According to Redzuan, Rahman \& Aidid (2009), three main factors ofIslamic life insurance are: (1) to save over a fixed period of time and contribute a certain amount of money to a Takaful fund, (2) to earn returns on contributions from investment in Syaria compliant instruments, 
and (3) to receive protection in the event of death to the participant prior to the maturity of the plan.

In family Takaful, each Takaful installment is divided and credited into two separate accounts, namely the participant's account (PA) and the participants special account (PSA). A substantial proportion of the installments are credited into the PA solely for the purpose of savings and investment. The balance of the installments is credited into the PSA as 'tabarru' or donation for the Takaful operator to pay the Takaful benefits to the heir (s) of any participant who may die before the maturity of the contract. The amount accumulated in the PA is invested in various businesses permitted by syaria and the profits are divided between the Takaful operators and the participants according to the agreed ratio.

Therefore, understanding the factors that can encourage family Takaful demand is crucial because the market is still grossly under-tapped. Based on the previous literature, the study of the demand for conventional life insurance has attracted the interest of many researchers in the past but only a small number of studies have been conducted examining the determinants of family Takaful demand, especially those that have focused on Malaysians (Redzuan, Rahman \& Aidid, 2009; Unanimous, 2009). Based on the scenario mentioned above, this study is undertaken to examine the determinants of family Takaful demand in the Malaysian context.

According to the study by Redzuan, Rahman \& Aidid (2009), they used economic determinants as their variables such as income, interest rates, inflation, savings, and stocks to examine the demand for family Takaful. The finding of their study indicates that per capita income is a robust predictor of family Takaful demand, while long term interest rate and the composite stock index have a significant relationship with family Takaful demand. However, a similar anonymous study in 2009 identified two main factors, namely economic and socio-demographic in determining the demand of family Takaful. Among these factors they demonstrate that income, Islamic banking development, education, dependency ratio, and muslim population factors are positively related to Takaful demand. On the other hand, inflation, real interest rate, financial development and life expectancy appear to be the significant factors that influence the total family Takaful demand in Malaysia.

It seems that there is a large gap in the literature in the field of family Takaful. For this particular study, the researcher has to rely on literature on life insurance in order to better understand the factors that determine family Takaful demand. From the literature, there are two streams of research on the determinants of family Takaful and life insurance, namely from the economic perspective (for example, Neumann, 1969; Cargill \& Troxel, 1979; Babble, 1981, 1985; Brown \& Kim, 1993; Outreville, 1996; Lim \& Haberman, 2004; Redzuan, Rahman \& Aidid, 2009; Ching, Kogid, \& Furuoka, 2010) and the socio-demographic perspective (for example, Hammond, Houston \& Melander, 1967; Duker, 1969; Headen \& Lee, 1974; Burnett \& Palmer, 1984; Truet \& Truet, 1990; Showers \& Shotick, 1994; Gandolfi \& Miners, 1996; Lin \& Grace, 2007; Yusof, Gbadamosi \& Hamadu, 2009 ).

\section{Determinants of Family Takaful Demand}

The following discussion is organized by taking into consideration the limitation of literature on family Takaful. From the literature review, the following are the economic and socio-demographic factors which determine life insurance demand which are presumed to be the same for family Takaful.

\subsection{Economic factors}

\subsubsection{Income}

Evidence from literature shows that the income variable has been identified to significantly affect life insurance/family Takaful demand (Hammond, Houston \& Melander, 1967; Duker, 1969; Neaumann, 1969; Fisher, 1973; Fortune, 1973; Campbell,1980; Cargill \& Troxel 1979; Ferber \& Lee, 1980; Burnett \& Palmer, 1984; Goldsmith, 1983; Babbel 1985; Lewis 1989; Truett \& Truett 1990; Showers \& Shotick, 1994; Gandolfi \& Miners, 1996; Browne \& Kim 1993; Outreville 1996; Beck \& Webb 2003; Hwang \& Gao 2003; Savvas, 2006; Li, Moshirian, Nguyen \& Wee, 2007; Redzuan, Abdul Rahman \& S. H. Aidid, 2009; Liebenberg, Carson \& Hoyt, 2010; Curak \& Gaspic, 2011). As income progresses to higher levels, substitutes for individual life insurance again become available (Hammond, Houston \& Melander, 1967) and as income increases, life insurance becomes relatively more affordable (Brown \& Kim, 1993). Similar results are consistent with previous studies which state that when income rises insurance becomes more affordable and the demand for family Takaful and life insurance increases (Redzuan, Abdul Rahman \& S.H.Aidid, 2009). The empirical evidence from Cyprus showed that for every $\mathrm{C} £ 100$ million increase in GDP there would be a $\mathrm{C} £ 10$ million increase in life insurance premiums (Savvas, 2006). However, despite a low income level in China and considerable variation in the levels of economic development among areas, the rapid economic growth as a whole over the past ten years has played an important role in encouraging people to purchase life insurance products (Hwang \& Gao 2003). 
H1: There is a positive relationship between income and family Takaful demand.

\subsubsection{Inflation}

Inflation has been identified as one of the factors that influence life insurance demand. Consumers are found to be sensitive to inflation, be it expected or realized, by reduced purchasing of life insurance (Babbel, 1981). It can be summarized that the cost of life insurance protection would increase with anticipated inflation resulting in a decline in life insurance sales. However, most studies reveal that the relationship between inflation and the demand for life insurance/family Takaful is not significant (Neumann, 1969; Fortune, 1973; Cargill \& Troxel 1979; Babble, 1981; Brown \& Kim, 1993; Chang, 1995; Hwang \& Gao 2003; Arena, 2006; Savvides, 2006; Li, Moshirian, Nguyen \& Wee, 2007; Redzuan, Abdul Rahman \& S.H.Aidid, 2009; Liebenberg, Carson \& Hoyt, 2010). Inflation is documented having an insignificant relationship because inflation itself can erode the value of life insurance, making it a less desirable good (Brown \& Kim, 1993; Redzuan, Abdul Rahman \& S.H.Aidid, 2009) as well as making it a less attractive product (Fortune, 1973). The negative impact of inflation also confirms that anticipated inflation depresses the value of financial assets and therefore reduces the attractiveness of life insurance products ( $\mathrm{Li}$, Moshirian, Nguyen \& Wee, 2007). On the other hand, there is no evidence found that the life insurance industry itself suffered an adverse impact over the periods of high inflation in China. This is because the period of high inflation was also a period of high economic growth, and in line with that, consumers were less sensitive to the negative impact of inflation as inflation did not have a detrimental effect on people's living standard (Hwang \& Gao, 2003).

$\mathrm{H} 2$ : There is a negative relationship between inflation and family Takaful demand.

\subsubsection{Interest Rate}

Several researchers have studied whether the interest rate variable plays a role in influencing life insurance demand. From the studies, it also helps to know whether consumers are really concerned with the market rates of interest when making decisions to purchase life insurance. The interest rate has shown different results in which some of the studies identified that there is a significant positive relationship between demand and interest rate (Chang, 1995; Beck \& Webb, 2003; Lim \& Haberman, 2004; Haiss \& Sumegi, 2008; Sen, 2008; Redzuan, Abdul Rahman \& S. H. Aidid, 2009).

However, other studies discovered that the interest rate is not a significant variable in determining life insurance/family Takaful demand and were found to be negatively correlated with the interest rate (Depamphils, 1975; Williams, 1986; Outreville,1996; Savvides, 2006; Li, Moshirian, Nguyen \& Wee, 2007; Nesterova, 2008; Sen, 2008).The demand for life insurance increased with higher interest rates in the short run situation, but was inconclusive in the long run situation (Headen \& Lee, 1974). Literature supports that a short term interest rate resulted in a significant relationship with universal life insurance, whereas current interest rates have a strong positive relationship with universal life insurance because the current interest rate of universal life insurance have been kept higher than the short term bases (Chang, 1995); domestic interest rate is statistically significant but inversely related to life insurance demand by supporting that a rise in real domestic interest will divert savings from long term funds to short term funds which tends to decrease life insurance demand (Ibiwoye, Ideji, Oke, 2010). The people are not attracted by lower price to increase the purchase of life insurance, but appear to take advantage of higher real rates in order to reduce the investment in life insurance and the real rates measure the preference for immediate as opposed to deferred consumption (Li, Moshirian \& Nguyen, 2007). Evidence from previous findings is clear, that consumers, especially in the observed countries, prefer investing in assets other than life insurance policies (Nesterova, 2008).

H3: There is a positive relationship between interest rate and family Takaful demand.

\subsubsection{Financial Development}

The findings from empirical study document a positive relationship between life insurance demand and the level of financial development (Outreville, 1996; Ward \& Zurbruegg, 2002; Beck \& Webb, 2003; Savvides, 2006; Li, Moshirian, Nguyen \& Wee, 2007; Chui \& Kwok, 2008, Sen, 2008). As the financial system matures as a whole, this would lead to a better supply of insurance products and thus raise the demand further (Sen, 2008). It was also shown that the financial intermediary sector is to complement insurance consumption in developed economies (Ward \& Zurbruegg, 2002); the countries with well-being developed banks have higher levels of life insurance consumption as well as increased consumer confidence in other financial institutions (Beck \& Webb, 2003); and as more financial assets are accumulated, the people will also purchase more life insurance ( $\mathrm{Li}$, Moshirian, Nguyen \& Wee, 2007). Due to this, financial development was introduced as financial intermediation which can be an important source of growth in the insurance and Takaful industry. 
H4: There is a positive relationship between financial development and family Takaful demand.

\subsubsection{Savings}

Saving instruments are the alternative that represents competing products of life insurance. The life insurance / family Takaful demand might be boost if savings plus life insurance products are sold (Sen, 2008). The impact of savings on life insurance demand has been studied in the past (Headen \& Lee, 1974; Chang, 1995; Beck \& Webb, 2003; Savvides, 2006; Sen \& Madheswaran, 2007; Sen, 2008; Redzuan, Abdul Rahman \& S.H.Aidid, 2009; Ibiwoye, Ideji, Oke, 2010).

Evidence from literature suggests that savings has a negative impact on life insurance/family Takaful demand (Beck \& Webb, 2003; Savvides, 2006; Redzuan, Abdul Rahman \& S. H. Aidid, 2009). Consumers prefer to consider other alternatives of saving if the effective return within an insurance policy is lower compared to those offered by other saving instruments (Redzuan, Abdul Rahman \& S. H. Aidid, 2009); there is a wealth-replacement effect which means that higher private savings displace life insurance and the higher the savings that an individual has, the less would be the motive to buy life insurance to supplement these financial resources in order to reach a targeted level of wealth for retirement or for bequeaths (Savvides, 2006).

Other results show that saving variable has a positive relationship with life insurance demand (Sen \& Madheswaran, 2007; Sen, 2008) and suggested that an increase in saving activity will enhance life insurance demand by increasing per capita insurance expenditure. Another result provided an ambiguous priority in the effect of personal savings rate on life insurance sales because an individual may have other investment alternatives besides the demand for life insurance (Chang, 1995).

H5: There is a negative relationship between savings and family Takaful demand.

\subsubsection{Unemployment}

Unemployment rate is defined as an indicator of income uncertainty and is also viewed as an uncertainty variable. A few studies have been carried out to explain the relationship between the demand for life insurance and unemployment rate (Mantis \& Farmer, 1968; Savvides, 2006; Lenten \& Rulli, 2006; Savvides, 2006). Results from the studies suggest that unemployment rate has a negative impact on life insurance demand (Mantis \& Farmer, 1968; Lenten \& Rulli, 2006; Savvides, 2006). This indicates that people are not sensitive to changes in these factors when they decide to take out life insurance (Savvides, 2006).

H6: There is a negative relationship between unemployment and family Takaful demand.

\subsubsection{Pensions}

Pension is a source of financing retirement and is considered as an alternative to private provisions. The growth of pensions has contributed to the decline in labour force participation at older ages (Samwick, 1998). Having adequate old-age pensions helps to encourage workers to retire earlier (Savvides, 2006). The existence of both private pensions as well as social security appears to have a negative effect on individual savings (King \& Mireaux, 1981).The estimated coefficients positive with regard to pensions variable, but in most models, they are not statistically significant (Savvides, 2006).

H7: There is a positive relationship between pensions and family Takaful demand.

\subsubsection{Stock}

Stock refers to the publicly traded stock (Lin \& Grace, 2007) and is defined as the ratio of the stock market capitalization to gross domestic product (Chui \& Kwok, 2008). Most studies examine the relationship between the performance level of stocks and the demand for life insurance/family Takaful (Headen \& Lee, 1974; Cargill \& Troxil, 1979; Zhu, 2007; Lin \& Grace, 2007; Lim \& Haberman, 2004; Arena, 2006; Chui \& Kwok, 2008; Redzuan, Abdul Rahman \& S. H. Aidid, 2009). These studies show that the level of stock has a positive relationship with life insurance demand (Arena, 2006; Zhu, 2007; Chui \& Kwok, 2008). For example, when an individual benefit from a rising stock market, he or she will invest more in life insurance (Arena, 2006).

In addition, some of the studies have found that the stock is negatively related with life insurance/family Takaful demand (Headen \& Lee, 1974; Cargill \& Troxill, 1979; Redzuan, Abdul Rahman \& S. H. Aidid, 2009). However, in other studies it is found that the stock market is also not statistically significantly related to the demand for life insurance which is contrary to their hypothesis, even though the past performance of the stock market in the immediate previous period a direct relationship with the demand for life insurance (Lim \& Haberman, 2004).This may explain that a higher price of stocks would stimulate the flow of funds that tend to depress life insurance/family Takaful sales (Haeden \& Lee, 1974; Redzuan, Abdul Rahman \& S. H. Aidid, 2009). 
H8: There is a positive relationship between stock and family Takaful demand.

\subsubsection{Price of Insurance}

The relationship between price of insurance and life insurance demand has been studied in the past (Mantis \& Farmer, 1969; Depamphills, 1975; Outreville, 1990; Outreville, 1996; Brown \& Kim, 1993;Ward \& Zurbruegg, 2002; Hwang \& Greenford, 2005; Savvides, 2006; Sen \& Madheswaran, 2007). However, the indicator of price of life insurance is not available in the most of the studies because it is difficult to determine the price of insurance with the various customised nature of policies (Outreville, 1996; Ward \& Zurbruegg, 2002; Hwang \& Geeenford, 2005; Savvides, 2006).

The findings of these studies indicates that price of insurance is positively related to life insurance demand (Mantis \& Farmer, 1969; Depamphills, 1975; Outreville, 1996; Ward \& Zurbruegg, 2002); the price of insurance variable is positive and statistically insignificant in the fixed effects model and is found negatively and statistically insignificant in the pooled cross-sectional model (Hwang \& Greenford, 2005). This is because the longer life expectancy which is used to proxy the price of insurance has a positive effect on life insurance demand by resulting in a reduction in the price of insurance which leads the people to use life insurance (Outreville, 1996); the researcher suggested that the lower the price of insurance, it is expected to encourage more life insurance demand (Hwang \& Greenford, 2005). Other empirical results showed that price of insurance are negatively related to life insurance demand (Outreville, 1990; Brown \& Kim, 1993); whereas another study concluded that price situation does not affect life insurance demand at all (Sen \& Madheswaran, 2007).

H9: There is a positive relationship between price of insurance / family Takaful and family Takaful demand.

\subsection{Socio-Economic}

\subsubsection{Life Expectancy}

Life expectancy is described as the number of years the average individual in a country is expected to live (Brown \& Kim, 1993). It is also described as the average time span a human has before death, calculated from the time of birth (Neterova, 2008). Life expectancy is measured by life expectancy of males at birth in the time-series estimations and measured by the age of the head of household in the cross-sectional regressions (Savvides, 2006).

The relationship between life expectancy has been studied by many researchers (Outreville, 1996; Brown \& Kim, 1993; Ward \& Zurbruegg, 2000; Beck\& Webb, 2003; Lim \& Haberman, 2004; Ward \& Zurbruegg, 2005; Savvides, 2006; Sen \& Madheswaran, 2007; Nesterova, 2008; Sen, 2008; Hussels, Li, Moshirian, Ngyuen \& Wee; 2009). Some empirical studies document a positive impact of life expectancy on life insurance demand (Outreville, 1996; Ward \& Zurbruegg, 2005; Savvides, 2006; Sen \& Madheswaran, 2007; Nesterova, 2008; Sen, 2008). Life expectancy was found to have a positive relationship with life insurance demand which was contrary to their expectation (Li, Moshirian, Ngyuen \& Wee, 2007). Life expectancy is found to positively related to the demand for life insurance, but it not statistically significant and has been removed from the estimation in their study (Lim \& Haberman, 2004). The positive relationship between life expectancy at birth and the demand for life insurance is explained as populations with a longer life span tend to buy life insurance policies because they expect to enjoy a lower cost for insurance, a greater incentive for human capital accumulation since the cost is being spread over a longer period and the cash value is being accumulated for a longer duration (Lim \& Haberman, 2004). This positive relationship is explained through the expectation that the longer the retirement span either due to earlier retirement or due to longer life expectancy, than the higher the share of income that people seek to save during their working life time to ensure adequate resources for retirement (Savvides, 2006). It also implies that the longer life duration reduces the price for life insurance and gives stimulus to purchase more of it in order to accumulate more capital through savings, therefore, the demand for life insurance products would be increased (Sen, 2008). However, some research (Brown \& Kim, 1993, Beck \& Webb, 2003) has shown that life expectancy is found to negatively relate to life insurance demand.

H9: There is a positive relationship between life expectancy and family Takaful demand.

\subsubsection{Dependency Ratio}

The dependency ratio is described as the demographic structure of the average household in terms of the number of family members dependent on the main source of income (Lenten \& Rulli, 2006). Empirical studies have shown that the dependency ratio is positively related to the demand for life insurance (Brown \& Kim, 1993; Chui \& Kwok, 2008; Curak \& Gaspic, 2011); and it has been found that the dependency ratio has a positive impact on foreign life insurance participation (Ye, Li, Chen \& Moshirian, 2009). The increasing number of dependents shows that the person needs to buy more life insurance (Chui \& Kwok, 2011). 
In line with this, findings of past studies have indicated that young dependency ratio is negatively related to life insurance demand (Beck \& Webb, 2003; Sen \& Madheswaran, 2007).It is expected that a young dependency ratio will increase the demand for mortality coverage and decrease the demand for savings through life insurance and annuities (Beck \& Webb, 2003). Whereas, an old dependency ratio is found to be positively related to the demand for life insurance (Beck \& Webb, 2003; Sen \& Madheswaran, 2007; Sen, 2008). This can be explained as the older population grows, there will be a higher demand for savings (Beck \& Webb, 2003).

H10: There is a positive relationship between dependency ration and family Takaful demand.

\subsubsection{Education}

The findings on the relationship between education and the demand for life insurance was found to have a positive effect (Hammond, Houston \& Melander, 1967; Ferber \& Lee, 1980; Burnett \& Palmer,1984; Truet \& Truet, 1990; Brown \& Kim, 1993; Gandolfi \& Miners, 1996; Hau. 2000; Hwang \& Gao, 2003; Baek \& Devaney, 2005; Hussels, Ward \& Zurbruegg, 2005; Savvides, 2006; Lin \& Grace, 2007; Nesterova, 2008; Yusuf, Gbadamosi \& Hamadu, 2009; Curak \& Gaspic, 2011); but in other studies, education was found to be negatively related (Duker, 1969; Anderson \& Navin, 1975; Auerbach \& Kotlikoff, 1989). Higher education increases life insurance demand because people can better identify the types of life insurance available as well as have a strong desire to provide protection for dependents against risks (Truet \& Truet, 1990; Baek \& Devaney, 2005); and increase the insurance mindedness that helps to purchase life insurance products more objectively (Hau, 2000). The educational level of the household also represents a positive attitude toward life insurance demand (Yusuf, Gbadamosi \& Hamadu, 2009). This may suggest people to have a greater awareness which can lead to an increase in the understanding of the importance of life insurance (Hammond, Houston \& Melander, 1967; Brown \& Kim, 1993; Hwang \& Gao, 2003; Savvides, 2006, Lin \& Grace, 2007; Nesterova, 2008; Curak \& Gaspic, 2011).

However, the findings in other studies reveal that education is negatively related (Duker, 1969; Anderson \& Navin, 1975; Auerbach \& Kotlikoff, 1989); and an insignificant relationship has been found between education and life insurance demand (Outreville, 1996; Beck \& Webb, 2003; Tan, Wong \& Law, 2009). The education level was found not to have a significant factor to determine life insurance demand because the people acquired the knowledge about life insurance from respective insurance agents and not from the formal education system (Tan, Wong \& Law, 2009).

H10: There is a positive relationship between education and family Takaful demand.

\subsubsection{Age}

In some literature, the findings showed that age is positively related to life insurance demand (Showers \& Shotick, 1994; Berekson, 1972; Truet \& Truet, 1990; Yusof, Gbadamosi \& Hamadu, 2009; Hwang \& Greenford, 2005, Tan, Wong \& Law, 2009; Liebenberg, Carson \& Hoyt, 2010). This is because an increase in age indicates a higher positive attitude toward insurance and people who are towards the end of an active life are more conscious of life after retirement (Yusof, Gbadamosi \& Hamadu, 2009).

But, it was disclosed that when people grow up they have a greater awareness on the need of life insurance but the need of life insurance will decline as the people reach beyond a certain age. Evidence supports that age was found to have negative impact on life insurance demand (Bernheim, 1991; Chen, Wong \& Lee, 2001; Ferber \& Lee, 1980; Savvides, 2006; Hau, 2000; Liebenberg, James \& Randy, 2010; Goldsmith, 1983). This can perhaps be explained as people are more likely to purchase life insurance for morbidity as well as for retirement purposes which vary with their affordability and not age (Chen, Wong \& Lee, 2001); as the average age of people increased the cost of obtaining coverage also increased and this can reduce the desirability of purchasing life insurance (Goldsmith, 1983); and for older people they are less likely to become involved in long-range planning (Savvides, 2006).

On the other hand, there are also some studies which indicate that age was not a significant factor influencing life insurance demand (Duker, 1969; Gandolfi \& Miners, 1996). One of the studies produced mixed result, for example, age becomes statistically significant in both low and middle income groups but not in the high income class (Hammond, Houston \& Melander, 1967).

H11: There is a positive relationship between age and family Takaful demand.

\subsubsection{Urbanisation}

The relationship between the urbanisation and life insurance demand has been identified in the previous studies (Neumann, 1969; Beck \& Webb, 2003; Hwang \& Gao, 2003; Savvides, 2006; Sen \& Madheswaran, 2007; 
Nestrova, 2008; Sen, 2008). The findings indicate that the urbanisation is statistically significant in which the demand for life insurance is likely to increase as there is a higher degree of urbanization (Hwang \& Gao, 1969; Savvides, 2003; Sen \& Madheswaran, 2007; Sen, 2008). The result of determinants for 12 Asian Economies found that the urbanisation variable is significant but it suggests that the life insurance demand decreased because of the migration of rural poor into the urban areas; whereas the result of determinants for India suggested that urbanisation has a positive coefficient because the more urban an area, the demand for life insurance would increase (Sen \& Madheswaran, 2007; Sen, 2008). The urbanisation has a positive relation because the increasing urbanisation level together with the economic progress can reduced the number of children and change the traditional economy as well by which the parents have to save funds in order to meet their retirement needs (Hwang \& Gao, 1969); and it is expected that the consumers who lived in an urban area also have a higher level of life insurance demand as costs related to marketing, premium collection underwriting and claim handling are reduced even though the result cannot explain the variation in life insurance penetration (Beck \& Webb, 2003).

However, in the other studies the results indicated that urbanisation has a negative coefficient (Neumann, 1969); the urbanisation level is found to be insignificant because it does not have a robust link to life insurance demand (Nestrova, 2008).

H12: There is a positive relationship between urbanisation and family Takaful demand.

\subsubsection{Household Size/Family Size/Number of Children}

The relationship between household size or number of children and life insurance demand has been studied by several researchers (Hammond, Houston \& Melander, 1967; Duker, 1969; Anderson \& Navin, 1975; Ferber \& Lee, 1980; Goldsmith, 1983; Skinner \& Dubinsky, 1984; Burnett \& Palmer, 1984; Shower \& Shotick, 1994; Gandolfi \& Miners, 1996; Savvides, 2006). Empirical studies have shown that the demand for life insurance is positively related to household size or family size (Hammond, Houston \& Melander, 1967; Shower \& Shotick, 1994; Savvides, 2006). The number of children is a positive significant variable because households with a large number of children have a greater demand for life insurance (Ferber \& Lee, 1980; Burnett \& Palmer, 1984). It was found that household size is a good predictor of life insurance demand (Savvides, 2006); as the household size increased by one person, the current purchasers of insurance also increase (Shower \& Shotick, 1994); and as the number of children increased, the amount of insurance also increased (Burnett \& Palmer, 1984).

In other studies, the relationship between the household size and life insurance demand is weak (Gandolfi \& Miners, 1996); the impact of household size on life insurance demand is found to be ambiguous and the larger households are less likely to purchase life insurance because the increase in household income due to an additional dependent is opposed by an increase in the cost of supporting a larger household (Goldsmith, 1983). Besides, the other findings showed that there is no significant impact between household size and the life insurance demand (Anderson \& Navin, 1975; Duker, 1969).

H13: There is a positive relationship between household size and family Takaful demand.

\subsubsection{Employment Status}

The relationship between employment status and the life insurance demand has been studied in the past (Mantis \& Farmer, 1968; Goldsmith, 1983; Skinner \& Dubinsky, 1984; Baek \& Devaney, 2005; Savvides, 2006; Liebenberg, James \& Randy, 2010); where the variables also include the labor force participation (Gandolfi \& Miners, 1996); and the occupation as well (Hammond, Houston \& Melander, 1967; Duker, 1969; Ferber \& Lee, 1996). Result from the studies suggest that employment status is a good predictor that influences the purchasing decision which can encourage life insurance demand (Black \& Skipper, 1993; Baek \& Devaney, 2005; Savvides, 2006); and the employment status of an individual also influence the life insurance purchasing decision (Black \& Skipper, 1993). Evidence has shown that both full and part time work has a positive impact on group life insurance ownership (Gandolfi \& Miners, 1996). The purchasing of face amounts of life insurance is influenced positively by a wife's working status (Ferber \& Lee, 1996); $a$ wife's employment status is an important factor in a family decision to purchase life insurance (Skinner \& Dubinsky, 1984); a household head's occupation was determined to be significant except for the middle and high income subgroups (Hammond, Houston \& Melander, 1967); and those who started with a new job were more likely to purchase life insurance (Liebenberg, James \& Randy, 2010). The employment status is positively related to life insurance demand because the higher status of people represents the people who are future oriented, more financially sophisticated and more concerning in educating their children (Duker, 1969); which accounted for a greater awareness of the need for life insurance (Hammond, Houston \& Melander, 1967). 
H14: There is a positive relationship between employment status and family Takaful demand.

\section{Proposed Framework}

Based on the pertinent literature discussed earlier, a conceptual framework for the determinant of family Takaful demand is developed (see Figure 1). This study suggests that several factors such as income, interest rate, financial development, pensions, stocks, price of insurance, life expectancy, dependency ratio, education, age, urbanisation, household size, employment status, inflation and savings are considered important factors that determine family Takaful demand. The proposed framework for this study is presented in Figure 1.

Insert Figure 1- here

From the above, the condition of family Takaful demand suggests that:

- There are positive relationships between variables such as income, interest rate, financial development, pensions, stocks, price of insurance, life expectancy, dependency ratio, education, age, urbanisation, household size and employment status with family Takaful demand.

- There are negative relationships between variables such as inflation, savings and unemployment rate with family Takaful demand.

Hence, this conceptual paper seeks to test the proposed framework of family Takaful demand in the context of Malaysia. It is worthwhile to do empirical studies to examine whether these factors are considered important and significant as mentioned in the proposed framework.

\section{Conclusion}

Much of the literature suggests that family Takaful business could contribute to the overall economic growth in Malaysia, hence the importance of this study. From the thorough review of related literature in this particular area of interest, there are nine (9) economic factors and seven (7) socio-economic factors that could possibly influence family Takaful demand. Further study is therefore needed to examine whether all of these factors contribute significantly to the family Takaful demand.

\section{References}

Anderson, D. R., \& Navin, J. R. (1975). Determinants of Young Marrieds' Life-Insurance Purchasing Behaviour: An Empirical Investigation. Journal of Risk and Insurance, 42(3), 375-387. http://dx.doi.org/10.2307/251694

Arena, M. (2008). Does Insurance Market Activity Promote Economic Growth? A Cross-Country Study for Industrialized and Developing Countries. Journal of Risk and Insurance, 75(4), 921-946. http://dx.doi.org/10.1111/j.1539-6975.2008.00291.x

Auerbach, A. J., \& Kotlikoff, L. J. (1989). How Rational is the Purchase of Life Insurance. National Bureau of Economic Research, 1-44.

Babbel, D. F. (1981). Inflation, Indexation, and Life Insurance Sales in Brazil. Journal of Risk and Insurance, 48(1), 111-135. http://dx.doi.org/10.2307/252655

Babbel, D. F. (1985). The Price Elasticity of Demand for Whole Life Insurance. Journal of Finance, 40(1), 225-239. http://dx.doi.org/10.2307/2328057

Baek, E., \& DeVaney, S. A. (2005). Human Capital, Bequest Motives, Risk, and the Purchase of Life Insurance. Journal of Personal Finance, 4(2), 62-84.

Bashir. M. S., \& Mail. N. H. H. (2011). Consumer Perception on Takaful Business in Brunei Darussalam. International Conference on Management Proceeding, 1144-1163.

Beck, T., \& Webb, I. (2003). Economic, Demographic, and Institutional Determinants of Life Insurance Consumption Across Countries. World Bank Economic Review, 17(1), 51-88. http://dx.doi.org/10.1093/wber/lhg011

Berekson, L. L. (1972). Birth Order, Anxiety, Affiliation and the Purchase of Life Insurance. Journal of Risk and Insurance, 39(1), 93-108. http://dx.doi.org/10.2307/251654

Bernhiem, B. D. (1991). How Strong Are Bequest Motives? Evidence Based on Estimates of the Demand for Life Insurance and Annuities. Journal of Political Economy, 99(5), 899-927. http://dx.doi.org/10.1088/261783

Brown, M. J., \& Kim, K. (1993). An International Analysis of Life Insurance Demand. Journal of Risk and Insurance, 60(4), 616-634. http://dx.doi.org/10.2307/253382

Burnett, J. J., \& Palmer, B. A. (1984). Examining Life Insurance Ownership through Demographic and 
Psychographic Characteristics. Journal of Risk and Insurance, 51, 453-467. http://dx.doi.org/10.2307/252479

Campbell, R. A. (1980). The Demand for Life Insurance: An Application of the Economics of Uncertainty. Journal of Finance, 35, 1155-1172. http://dx.doi.org/10.2307/2327091

Cargill, T. F., \& Troxel, T. E. (1979). Modeling Life Insurance Savings: Some Methodological Issues. Journal of Risk and Insurance, 46(3), 391-410. http://dx.doi.org/10.2307/252455

Carson, J. M. (1996). Determinants of Universal Life Insurance Cash Values. Journal of Risk and Insurance, 63(4), 673-681. http://dx.doi.org/10.2307/253477

Chang, D. H. (1995). Economic Analysis of the Development of Universal Life Insurance in the 1980s.Journal of American Society of CLU \& ChFC, 49(1), 82-87.

Chen, R., Wong, K. A., \& Lee, H. C. (2001). Age, Period, and Cohort Effects on Life Insurance Purchases in the U.S. Journal of Risk and Insurance, 68(2), 303-327. http://dx.doi.org/10.2307/2678104

Chui, A. C. W., \& Kwok, C. C. Y. (2008). National Culture and Life Insurance Consumption. Journal of International Business Studies, 39, 88-101. http://dx.doi.org/10.1057/palgrave.jibs.8400316

Curak, M., \& Kljakovic, M. (2011). Economic and Social Determinants of Life Insurance ConsumptionEvidence from Central and Eastern Europe. Journal of American Academy of Business, 16(2), 216-222.

Depamphilis, D. M. (1977). Variation in Individual Life Insurance Premium Revenues: An Econometric Approach. Journal of Risk and Insurance, 44(1), 67-76. http://dx.doi.org/10.2307/251857

Devasenathipathi.T., Saleendran. P. T., \& Shanmugasundaram, A. (2007). A Study on Consumer Preference and Comparative Analysis of All Life Insurance Companies. The Icfai Journal of Consumer Behavior, II, 4, 8-16.

Duker, J. M. (1969). Expenditures for Life Insurance among Working-Wife Families. Journal of Risk and Insurance, 36(5), 525-533. http://dx.doi.org/10.2307/251159

Epetimehin, F. M. (2011). A Study of the Factors Enhancing the Purchase of Life Insurance in Nigeria. International Business Management, 5(3), 124-128. http://dx.doi.org/10.3923/IBM.2011.124.128

Ferber, R., \& Lee, L. C. (1980). Acquisition and Accumulation of Life Insurance in Early Married Life.Journal of Risk and Insurance, 47(4), 713-734. http://dx.doi.org/10.2307/252292

Fortune, P. (1973). A Theory of Optimal Life Insurance: Development and Tests. Journal of Finance, 28, 587-600. http://dx.doi.org/10.2307/2978631

Gandolfi, A. S., \& Miners, L. (1996). Gender-Based Differences in Life Insurance Ownership. Journal of Risk and Insurance, 63(4), 683-693. http://dx.doi.org/10.2307/253478

Goldsmith, A. (1983). Household Life Cycle Protection: Human Capital versus Life Insurance. Journal of Risk and Insurance, 50(3), 473-485. http://dx.doi.org/10.2307/252438

Haiss, P., \& Siimegi, K. (2008). The Relationship between Insurance and Economic Growth in Europe: A Theoretical and Empirical Analysis. Empirica, 35(4), 405-431. http://dx.doi.org/10.1007/s10663-008-9075-2

Hammond, J. D., Houston, B. D., \& Melander, R. E. (1967). Determinants of Household Life Insurance Premium Expenditures: An Empirical Investigation. Journal of Risk and Insurance, 34(3), 397-408. http://dx.doi.org/10.2307/250854

Hau, A. (2000). Liquidity, Estate Liquidation, Charitable Motives, and Life Insurance Demand by Retired Singles. Journal of Risk and Insurance, 67(1), 123-141. http://dx.doi.org/10.2307/253680

Headen, R. S., \& Lee, J. F. (1974). Life Insurance Demand and Household portfolio Behavior. Journal of Risk and Insurance, 41(4), 685-698. http://dx.doi.org/10.2307/251963

Hussels, S., Ward, D., \& Zurbruegg, R. (2005). Stimulating the Demand for Insurance.Risk Management and Insurance Review, 8(2), 257-278. http://dx.doi.org/10.1111/j.1540-6296.2005.00059.x

Hwang, T., \& Gao, S. (2003). The Determinants of the Demand for Life Insurance in an Emerging Economy The Case of China. Journal of Managerial Finance, 29(5/6), 82-96. http://dx.doi.org/10.1108/03074350310768779

Hwang, T., \& Greenford, B. (2005). A Cross-Section Analysis of the Determinants of Life Insurance Consumption in Mainland China, Hong Kong, \& Taiwan. Risk Management \& InsuranceReview, 8(1), 103-125. http://dx.doi.org/10.1111/j.1540-6296.2005.00051.x

Ibiwoye, A., Ideji, J. O., \& Oke, B. O. (2010). The Determinants of Life Insurance Consumption in Nigeria: A 
Co-Integration. International Journal of Academic Research, 2(4), 351-358.

King, M. A., \& Mireaux, L. D. (1981). Asset Holding and the Life Cycle. National Bureau of Economic Research, 1-52.

Lenten, L. J. A., \& Rulli, D. N. (2006). A Time-Series Analysis of the Demand for Life Insurance Companies in Australia: An Unobserved Components Approach. Australian Journal of Management, 31(1), 41-66. http://dx.doi.org/10.1177/031289620603100104

Liebenberg, A. P., Carson, J. M., \& Hoyt, R. E. (2010). The Demand for Life Insurance Policy Loans. Journal of Risk and Insurance, 77(3), 651-666.

Liebenberg, A. P., Carson, J. M., \& Dumm, R. E. (2010). A Dynamic Analysis of the Demand for Life Insurance. Journal of Risk and Insurance, 1-28.

Li, D., Moshirian, F., Nguyen, P., \& Wee, T. (2007). The Demand for Life Insurance in OECD Countries. Journal of Risk and Insurance, 74(3), 637- 652. http://dx.doi.org/10.1111/j.1539-6975.2007.00228.x

Mantis, G., \& Farmer, R. N. (1968). Demand for Life Insurance. Journal of Risk and Insurance, 35(2), 247-256. http://dx.doi.org/10.2307/250834

Maysami, R. C., \& Williams, J. J. (2006). Evidence on the Relationship between Takaful Insurance and Fundamental Perception of Islamic Principles. Applied Financial Economics Letters, 2, 229-232. http://dx.doi.org/10.1080/17446540500461778

Nesterova, D. (2008). Determinants of the Demand for Life Insurance: Evidence from Selected CIS and CEE Countries. National University "Kyiv-Mohyla Academy", 1-49.

Neumann, S. (1969). Inflation and Saving Through Life Insurance. Journal of Risk and Insurance, 36(5), 567-582. http://dx.doi.org/10.2307/251163

Outreville, J. F. (1990). The Economic Significance of Insurance Markets in Developing Countries. Journal of Risk and Insurance, 18(3), 487-498. http://dx.doi.org/10.2307/252844

Outreville, F. J. (1996). Life Insurance Markets in Developing Countries. Journal of Risk and Insurance, 63(2), 263-278. http://dx.doi.org/10.2307/253745

Redzuan, H., Rahman, Z. A., \& Aidid, S. S. S. H. (2009). Economic Determinants of Family Takaful Consumption: Evidence from Malaysia. International Review of Business Research Papers, 5(5), 193-211.

Sekaran, Uma. (2000). Research Methods for Business. (3rd ed.). New York: John Wliley \& Sons.

Samwick, A. A. (1998). New Evidence on Pensions, Social Security, and the Timing of Retirement. Journal of Public Economics, 70, 207-236. http://dx.doi.org/10.1016/S0047-2727(98)00022-X

Savvides, S. (2006). Inquiry into the Macroeconomic and Household Motives to Demand Life Insurance: Review and Empirical Evidence from Cyprus. Journal of Business and Society, 19, 37-79.

Sen, S. \& Madheswaran, S. (2007). Are Life Insurance Demand Determinants valid for Selected Asian Economies and India? Paper for Presentation at Annual Meeting of APRIA, 1-27.

Sen, S. (2008). An Analysis of Life Insurance Demand Determinants for Selected Asian Economies and India. Working Paper, 36, 1-44. [Online] Available: http://www.mse.ac.in/pub/working\%20paper\%2036.pdf

Showers, V. E., \& Shotick, J. A. (1994). The Effects of Household Characteristics on Demand for Insurance: A Tobit Analysis. Journal of Risk and Insurance, 61(3), 492-502. http://dx.doi.org/10.2307/253572

Skinner, J., \& Dubinsky, A. J. (1984). Purchasing Insurance: Predictors of Family Decision-Making Responsibility. Journal of Risk and Insurance, 51(3), 514-523. http://dx.doi.org/10.2307/252483

Tan, H. B., Wong, M. F., \& Law, S. H. (2009). The Effect of Consumer Factors and Firm Efficiency on Malaysian Life Insurance Expenditure. International Journal Business and Society, 10(1), 59-73.

Truett, D. B., \& Truett, L. J. (1990). The Demand for Life Insurance in Mexico and the United States: A Comparative Study. Journal of Risk and Insurance, 57(2), 321-328. http://dx.doi.org/10.2307/253306

Ward, D., \& Zurbruegg, R. (2000). Does Insurance Promote Economic Growth? Evidence from OECD Countries. Journal of Risk and Insurance, 67(4), 489-506. http://dx.doi.org/10.2307/253847

Ward, D., \& Zurbruegg, R. (2002). Law, Politics and Life Insurance Consumption in Asia. Geneva Papers on Risk and Insurance, 27(3), 395-412. http://dx.doi.org/10.1111/1468-0440.00181 
Williams, C. A. (1986). Higher Interest Rates, Longer Lifetimes and the Demand for Life Annuities. Journal of Risk and Insurance, 53(1), 164-171. http://dx.doi.org/10.2307/252274

Ye, D., Li, D., Chen, Z., Moshirian, F., \& Wee, T. (2009). Foreign Participation in Life Insurance Markets: Evidence from OECD Countries. The Geneva Papers, 34, 466-482. http://dx.doi.org/10.1057/gpp.2009.9

Yusof, T. O., Gbadamosi, A., \& Hamadu, D. (2009). Attitudes of Nigerians towards Insurance Services: An Empirical Study. African Journal of Accounting, Economics, Finance, and Banking Research, 4(4), 34-46.

Yusof, M. E., \& Shamsuddin. A. S. (2003). Muslim Consumers Attitude towards Islamic Finance Products in a Non Muslim Country. Jurnal Kemanusian, 94-103.

Zhu, Y. (2007). One-Period Model of Individual Consumption, Life Insurance, and Investment Decisions. Journal of Risk and Insurance, 74(3), 613-636. http://dx.doi.org/10.1111/j.1539-6975.2007.00227.x

Table 1. Takaful Business Performance in 2005 to 2009

\begin{tabular}{|l|l|l|l|l|l|l|l|l|l|}
\hline RM Million & 2006 & 2007 & Growth & 2007 & Growth & 2008 & Growth & 2009 & Growth \\
\hline Family Takaful & 725 & 1,267 & $74.6 \%$ & 1,452 & $14.7 \%$ & 1,980 & $36.3 \%$ & 2,178 & $10.0 \%$ \\
\hline General Takaful & 551 & 704 & $27.7 \%$ & 687 & $-2.3 \%$ & 853 & $24.0 \%$ & 1,053 & $23.5 \%$ \\
\hline Total & 1,277 & 1,970 & $54.3 \%$ & 2,140 & $8.6 \%$ & 2833 & $32.4 \%$ & 3,231 & $14.1 \%$ \\
\hline
\end{tabular}

Source: ISM as cited in Etiqa Takaful Berhad: Evaluation of the Malaysian Takaful Industry

Table 2. Takaful and Conventional Insurance Fund Assets

\begin{tabular}{|l|l|l|l|l|}
\hline \multicolumn{5}{|c|}{ Takaful Fund Assets } \\
\hline Total (RMb) & 2006 & 2007 & 2008 & 2009 \\
\hline Family & 6.89 & 8.81 & 10.5 & 12.4 \\
\hline General & 5.8 & 7.4 & 8.9 & 10.5 \\
\hline \% of Gross Nasional Income & 1.1 & 1.4 & 1.7 & 1.9 \\
\hline \% of total asssets of the insurance and Takaful industry & 1.2 & 1.6 & 1.5 & 1.9 \\
\hline
\end{tabular}

Source: Bank Negara Malaysia (2010)

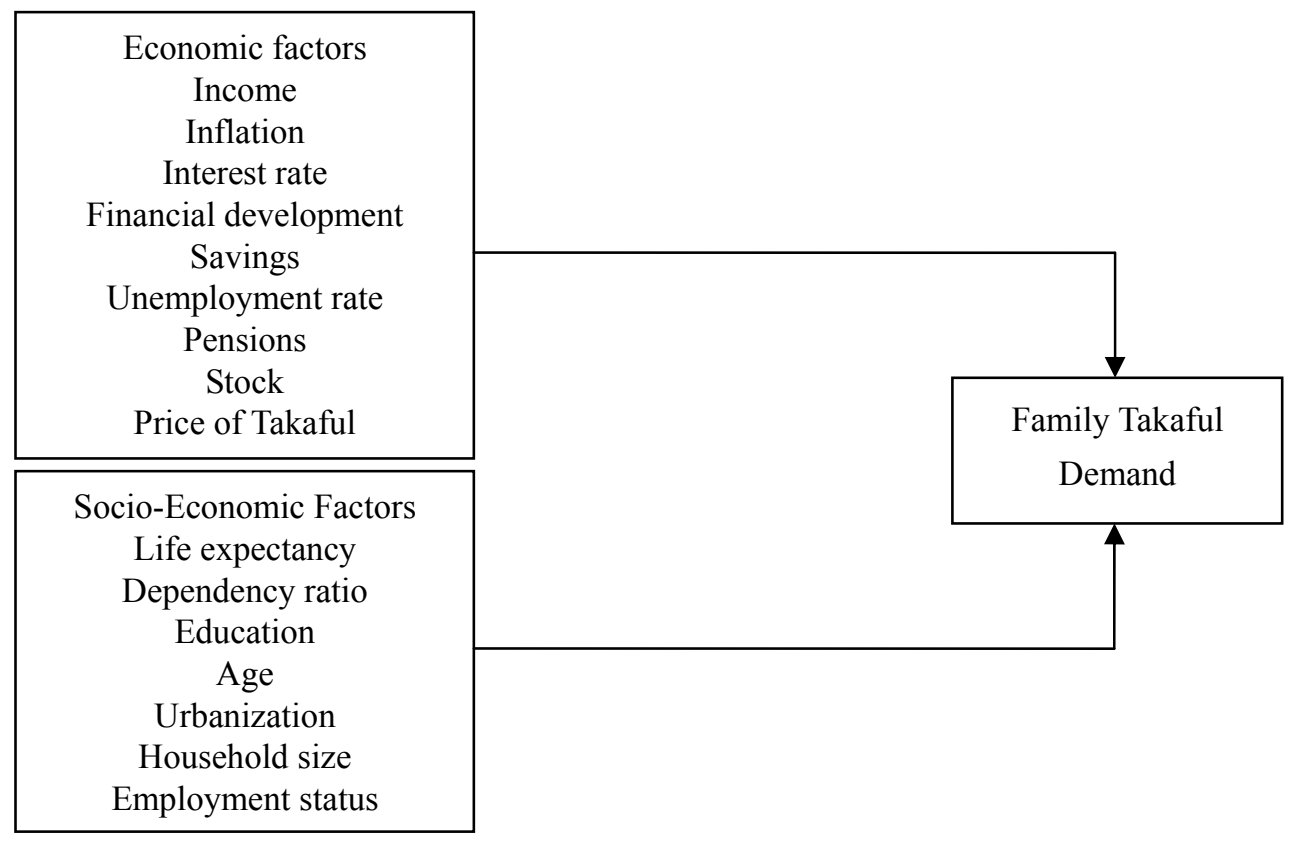

Figure 1. Conceptual Framework 